\title{
The Trial of Jacob Benjamin, Supplier to the French Army, 1792-93
}

Ronald Schechter

College of William and Mary, rbsche@wm.edu

Follow this and additional works at: https://scholarworks.wm.edu/asbookchapters

Part of the European History Commons, and the Jewish Studies Commons

\section{Recommended Citation}

Schechter, R. (2016). The Trial of Jacob Benjamin, Supplier to the French Army, 1792-93. Zvi Jonathan Kaplan and Nadia Malinovich (Ed.), Re-examining the Jews of Modern France: Images and Identities (pp. 33-61). Leiden: Brill. https://scholarworks.wm.edu/asbookchapters/74

This Book Chapter is brought to you for free and open access by the Arts and Sciences at W\&M ScholarWorks. It has been accepted for inclusion in Arts \& Sciences Book Chapters by an authorized administrator of W\&M ScholarWorks. For more information, please contact scholarworks@wm.edu. 


\title{
The Trial of Jacob Benjamin, Supplier to the French Army, 1792-93
}

\author{
Ronald Schechter
}

\section{Introduction}

On November 8, 1792 Deputy Pierre-Joseph Cambon addressed his fellow lawmakers in the National Convention, the newly-formed legislature of a French Republic that was barely one month old and at war with formidable foreign enemies. He spoke in his capacity as a member of the Finance Committee, and he had bad news about how the nation was spending its money for the provisioning of its armies. Specifically, he reported that his committee "has charged me with denouncing to you numerous fraudulent contracts agreed upon by [Jacques] Vincent, Chief Pay Commissioner for the Army of the South." Vincent had paid "nearly twice as much as the ordinary market price” for provisions, and Cambon promised to prove this by showing the deputies two agreements the commissioner had contracted with someone Cambon simply called "le juif Benjamin,” or “the Jew Benjamin.”

Both contracts had been signed in September, 1792. One was for 500 cavalry horses, which Jacob Benjamin sold the army for 720 livres each or 360,000 livres altogether. The other contract was even larger. It was "for the provisioning of Briançon,” a fortressed Alpine city constructed by Louis XIV’s military engineer Vauban in the seventeenth century, "and the forts that depend on it." In this deal Benjamin sold 8000 pounds of salt beef and 3600 pounds of salt pork. He also sold 300 sheep, 24,600 pounds of rice, 48,000 pounds of dried vegetables, 30,000 pounds of potatoes, 192,000 pints of wine, 1200 pounds of tobacco, 6000 pipes for smoking the tobacco, 12,800 pairs 
of linen stockings and the same number of shoes. This agreement was worth approximately 400,000 livres. $^{1}$

Although Cambon did not provide a basis for comparison, he claimed that Benjamin had overcharged the army, and he blamed Commissioner Vincent for signing off on the deals. Other deputies shared Cambon's indignation, and at the end of the session the lawmakers called for Vincent and Benjamin to be summoned to the bar of the Convention to account for their actions. ${ }^{2}$

Thus began a cause célèbre that occupied a great deal of the Convention’s time and energy over the course of two months and ended in a criminal trial of both Benjamin and Vincent in Lyon. This case, and the documentation it generated, reveal an extraordinary situation. In 1791, following much debate, the National Assembly had removed the legal barriers separating Jews and Gentiles, and the very next year the French government was relying to an astonishing degree on a single Jewish entrepreneur to supply its imperiled armies. While Cambon mentioned two contracts worth over 750,000 livres, other documents (now in the Archives départementales du Rhône) reveal that Benjamin did approximately four million livres worth of business with the Army of the South alone, and that he also supplied two other armies: the Army of Rhine and the Army of the Center. Not only might all this business have made Benjamin one of the richest people in France, it also indicates that he shares credit with other, more famous

\footnotetext{
1 Jérôme Mavidal, et al., eds., Archives parlementaires de 1787 à 1860, première série (1787-1799), 101 vols (Paris: 1867-2005), vol. 53, 309. The prices for each item were as follows: salt beef at 27 sous (one livre, 7 sous) per pound; salt pork at 36 sous, 6 deniers per pound; sheep (mutton) at 23 sous per pound; rice at 66 livres per quintal (100 pounds); dried vegetables at 34 livres, 10 sous per quintal; potatoes at 9 livres, 5 sous per quintal; wine at 18 sous, 6 deniers per pint; tobacco at 18 sous per livres; pipes at 9 deniers each; stockings at 13 livres per pair; and shoes at 13 livres per pair. There were 20 sous per livre and 12 deniers per sou.

${ }^{2}$ Archives parlementaires, vol. 53, 309-11.
} 
"architects of victory" such as Lazare Carnot. ${ }^{3}$ It is worth remembering that the Army of the Center, disbanded after the famous Battle of Valmy, had saved France from the Prussians, and that the Army of the Rhine (for which the Marseillaise was composed) carried the war into Germany itself, conquering the cities of Mainz, Landau, Speyer and Worms. Meanwhile the Army of the South protected France from allies of the deposed Bourbon dynasty in Italy by annexing Savoy. Contemporary documents suggest that many thousands of the men in these armies were eating food, wearing clothing and sleeping in tents provided by le juif Benjamin.

If only for these reasons, Jacob Benjamin should be known to students of French and Jewish history alike. ${ }^{4}$ Yet there is still more to his significance. There is evidence that Benjamin was part of a larger but historiographically overlooked network of Jewish businessmen who supplied the army. Benjamin partnered with at least five major Jewish entrepreneurs, and he had 300 préposés or agents working for him. Though it is impossible to know how many of them were Jewish, it would be surprising if Benjamin’s coreligionists did not make up a large contingent of his enterprise. Among the Jews who participated in Benjamin’s business was his wife, who published an open letter to the Convention — probably the first publication in France by a Jewish womanin which she defended her husband's conduct and simultaneously revealed a remarkable familiarity with the details of his business. Benjamin’s Jewish network affords a new perspective on emancipation. Historians, myself included, have tended to see

\footnotetext{
${ }^{3}$ I am grateful to Gail Bossenga of Elizabethtown College for suggesting the applicability of the term "architect of victory" to Benjamin.

${ }^{4}$ The only mention I have been able to find of Benjamin in the secondary literature on the French Revolution is a brief discussion in Jean Jaurès's multivolume Histoire socialiste de la Révolution Française (Paris, 1901-1907), vol. 3, 299-300. The only mention I have been able to find in the Jewish historiography is half a sentence in Z[osa] Szajkowski, "French Jews in the Armed Forces during the Revolution of 1789," Proceedings of the American Academy for Jewish Research, vol. 26 (1957): 156.
} 
emancipation in terms of the acquisition of political rights, but the case of Benjamin shows that more was at stake than the ability to vote and serve in public office. Benjamin and his Jewish colleagues no doubt appreciated these indicators of belonging to the French nation, but at a more concrete, practical, everyday level the Revolution provided them with a livelihood. Above all, the story of Jacob Benjamin reveals a great deal about Jewish-Gentile relations in the immediate aftermath of emancipation. Specifically, it reveals the weakness of antisemitism in 1792 and 1793. Although some revolutionaries referred to le juif Benjamin, anti-Jewish prejudice was not sufficient to convict the Jewish supplier. Nor did his acquittal spark any perceptible antisemitic response.

\section{The Convention Investigates Benjamin}

Benjamin appeared before the Convention on November 13. There he came face to face with a formidable array of revolutionary deputies. The encounter began when Hérault de Séchelles, President of the Convention (and future member of the Committee of Public Safety), read the arraignment decree and "invite[d] [Benjamin] to present his means of defense.” Benjamin responded by highlighting his expenses, citing, for example, the high costs of transporting goods to an army that was "dispersed over a radius of 120 leagues [414 miles].” Even when he had supplied a fixed encampment, such as the fortress of Briançon, he had to pay dearly for transportation. "Everyone knows," he told the deputies, "that to transport a quintal [100 pounds] of merchandise from Lyon to Briançon now costs 18 livres," adding, "[W]hen it is necessary to supply in a hurry everything is more expensive; that is a truth that cannot be denied.” Benjamin also invoked the satisfaction of the soldiers, declaring, "I abide by the soldiers; they will 
say how I served them and if they are happy.” He added that certificates of reception showed that "my supplies were all of good quality," and he finished his initial statement by saying, "I await with confidence and without fear the verdict of the Convention."

Cambon was not convinced. He claimed that, according to the Minister of War himself, salt pork was selling for 10 sous per pound in assignats (the revolutionary paper money that was subject to inflation), whereas Benjamin had charged 37 sous, half payable in specie. He ridiculed Benjamin's claim to have favorable certificates of reception, asserting that “at excessive prices ... such certificates are not difficult to obtain” and implying that Benjamin had purchased them through bribery. At this point "many members" of the Convention, according to the Archives parlementaires, called for Benjamin to be placed under arrest. Benjamin insisted that the price he asked for salt pork was at or even below market value. But his main argument was that General Montesquiou, commander of the Army of the South at the time of the contracts, had agreed to his terms. He asserted:

I am a supplier; the general either had the right to deal with me, or he did not; if he had the right, it is up to me to fulfill my engagements ... if he did not have the right, why did he deal with me?

Benjamin concluded, “[I]t was necessary for me to fulfill my promises, which I did; the nation has nothing more to ask of me.” This statement provoked "prolonged murmurs." Several members of the Convention responded to Benjamin's statements. LouisPierre Manuel insisted, "Let Benjamin go to the Committee of Surveillance, [and] he will say what bribes he dispensed.” The future member of the Committee of Public Safety Jacques Nicolas Billaud-Varenne hinted darkly, "I have facts to expose between the 
suppliers and the generals; I will produce them at the committee.” Jean-Lambert Tallien, also a future terroriste, declared:

Seals have been apposed to Benjamin's papers, [and] we will discover later whether he was not the front for some generals; but for the moment, I observe that the discussion which is about to open up is too interesting for the members of the Committee of Surveillance to be absent from it.

He concluded, "I ask that the Convention send Benjamin Jacob [sic] to the joint committees on finance, war and general security to be heard, and order that he remain in the meantime under arrest.” The Convention decreed Tallien’s proposal, then moved on to the business of deciding the fate of another detained person, namely the king. ${ }^{5}$

That same day, Benjamin was interrogated by Deputy Joseph-Mathurin Musset, who represented the joint committee. The resulting report, signed by Musset, was subsequently sent to the Criminal Tribunal in Lyon and is now in the Archives Départementales du Rhône. It reveals a great deal about the nature and extent of Benjamin’s business. When asked about his contracts with war ministers, Benjamin answered that in a contract with the Comte de Narbonne he had agreed to deliver shoes and stockings (he did not say how many) for the Army of the Rhine and the Army of the Center. (Narbonne was a Girondin War Minister who had emigrated after the fall of the monarchy on August 10, 1792.) Benjamin had also signed an agreement with Pierre Marie de Grave — who had been War Minister from March 9, 1792 to May 9, 1792_and who had contracted him to supply "twenty and some thousand shirts.” Finally, he had made a deal for the supply of meat with Minister of War Joseph Servan in June. These

\footnotetext{
${ }^{5}$ Archives parlementaires, vol. 53, 384-5.
} 
contracts were all in addition to the deals Benjamin made with Vincent under the authorization of General Montesquiou.

Musset’s interrogation also tells us about Benjamin’s business contacts. Benjamin denied the allegation (made three times by Musset) that his father-in-law had lent Narbonne 150,000 livres between 1786 and 1792, thereby implying that the discredited War Minister had had a conflict of interest when negotiating with Benjamin. Benjamin, however, revealed a network of business associates including his father-inlaw, his younger brother, a partner named Emmanuel Ducas and another named Chemol (spelled 'Schemolle' in other documents). ${ }^{6}$

On November 18 it was Vincent's turn to face the Convention. He told the deputies of a contract he had signed with Benjamin for 400 soldiers’ tents and one for 1800 beds for the soldiers stationed in Briançon. Vincent had also purchased 30,000 ells (45,000 feet) of cloth for soldiers' uniforms, as well as shirts, hats, and leggings. When asked about the allegedly high prices he had agreed to pay for Benjamin’s supplies, Vincent defended himself by claiming that he had bargained Benjamin down by 10 sous per pair of leggings, and by 4 sous per pound of lamb, and that he also obtained a discount on cloth for the soldiers’ uniforms. ${ }^{7}$ When asked by Abbé Grégoire, the radical priest and current President of the Convention, whether he knew of any "deals made between Benjamin Jacob [sic] and General Montesquiou,” he answered:

I am profoundly humiliated by this question; my life is without a stain; I have no knowledge of secret deals with General Montesquiou, and despite my friendship for him, if he had made himself guilty, I would have denounced him myself.

\footnotetext{
6 “Interrogatoire de Jacob Benjamin du 13 9bre l’an 1er [de la République],” 39 L 21, Archives Départementales du Rhône, Lyon. I am grateful to Etienne Faugier for photographing the documents relating to the Benjamin case at the $\mathrm{AD}$ du Rhône and sending them to me electronically.

${ }^{7}$ Archives parlementaires, vol. 53, 466-7.
} 
Despite his protestations of innocence, the Convention voted to keep Vincent under arrest and to send him before the Committee of General Security. ${ }^{8}$

The Convention became even more suspicious of Benjamin and Vincent when it received a letter on November 20 from three of its deputies who had been sent as observers to Lyon. These deputies_-Charles-Jean-Marie Alquier, François Antoine de Boissy d'Anglas and Louis Vitet—had recently visited the army’s storage facility in Lyon and examined some of the supplies within it. They claimed to have scrutinized some of the 200,000 pairs of shoes and 200,000 shirts that two other army suppliers (Lajard and Lebrun) had delivered, and they judged these to have been of very poor quality. They even sent six of the shirts to the Convention to prove how shoddy they were. It was not clear whether or how Benjamin was involved in this deal, but the letter began by denouncing "the enormity of the theft committed by Benjamin and his accomplices.” It also claimed that in the contract that Benjamin and Vincent had signed for the delivery of cloth (to be used in the production of uniforms) only the length, but not the width, had been stipulated, leaving Benjamin with the option of skimping on the total amount. It went on to claim that there was a vast conspiracy of army officials and suppliers to defraud the Republic. After hearing the contents of the letter, numerous deputies expressed outrage and called for severe measures against the accused. Jean-Bon-SaintAndré, who would later serve on the Committee of Public Safety, proclaimed, "It is only the scaffold that will dispense justice to those men who show the barbarity of enriching themselves at the expense of the unhappy soldiers of the Republic.” He called for an indictment against Benjamin and Vincent and for wide powers of arrest for the deputies

\footnotetext{
${ }^{8}$ Archives parlementaires, vol. 53, 384-5.
} 
observing the situation in Lyon. The Convention voted in favor of his proposal, though the indictment would only be drawn up on December 25. It also voted to create a commission of 24 deputies charged with investigating the contracts made between provisioners and army officials. ${ }^{9}$

To make matters worse, that same day President Grégoire announced that he had just received a letter from Jean-Nicolas Pache, Minister of War, which would serve as “a supplement to the general disturbance of the swindlers.” The letter announced that Pache had sent the Convention "a pair of shoes, a shirt and numerous pairs of socks supplied to the storage facility of Strasbourg by Jacob Benjamin.” These items, according to the Minister of War, had been rejected by a commissioner from the Army of the Rhine who was responsible for inspecting military supplies. Pache asserted that the shoes were "of the worst quality," that the shirt was "almost as coarse as packing-cloth," and that the socks were too thin. He also claimed that seals of approval from the Ministry of War had been removed from letters and affixed onto the socks, thus fraudulently giving the impression that the army had accepted the merchandise. He therefore saw it as his "duty to denounce this new form of peculation to the Convention.” Pache’s letter prompted still more comments about profiteering suppliers and corrupt army officials. ${ }^{10}$ According to the Archives Parlementaires 23 deputies spoke during the debates on army suppliers at the November 20 session. Clearly the matter was of great interest to the Convention, and the discussion might have continued even longer had Minister of Justice Roland not

\footnotetext{
9 Archives parlementaires, vol. 53, 489.

${ }^{10}$ Several non-Jewish army suppliers were also denounced.
} 
appeared with more pressing news: incriminating documents against the deposed king had been discovered in the Tuileries Palace. ${ }^{11}$

On November 28 the Convention read another letter from its representatives in Lyon. They had returned to the military storage facility and merchandise that had been accepted by “guilty military commissioners and inspectors” was “recognized” (presumably by Alquier, Boissy d'Anglas and Vitet themselves) as “of the worst quality.” The implication was that military officials in charge of the storage facility and the experts contracted to inspect the merchandise had been bribed. There is no record in the Archives Parlementaires as to the response of the deputies in Paris, who spent much of the November 28 session discussing the fate of Louis XVI, but for Benjamin the accusations were clearly accumulating.

On December 7 the Committee on Legislation proposed sending Benjamin and Vincent to the criminal tribunal of the Department of Rhône-et-Loire in Lyon. Up to this point it had not been clear where the suspects would be tried, but trying them before the Convention was obviously not practical considering that this assembly was now functioning as court to a much more important trial: that of the deposed king. The Convention accepted the committee’s recommendation, and Benjamin and Vincent departed for Lyon, where they would be held in the jail of the Palais de Justice until their trial. $^{12}$

${ }^{11}$ Archives parlementaires, vol. 53, 491.

${ }^{12}$ Archives parlementaires, vol. 54, 405. 


\section{Madame Benjamin Appeals to the Convention}

At some point between November 20 and December 7 an extraordinary publication appeared: La femme de Jacob Benjamin à la Convention Nationale. This undated 22-page pamphlet is historically valuable at several levels. It reveals the close involvement of Benjamin's wife (who did not provide her given name) in her husband's affairs and thereby gives a tantalizing glimpse into the role Jewish women may have played in their families' businesses. It is also probably the first publication in France ever written by a Jewish woman. (Of course it is possible that Madame Benjamin had help in composing the pamphlet.) Moreover, it demonstrates her skill in taking a legal case to the tribunal of public opinion, a strategy that Sarah Maza has shown to have been popular under the Old Regime. ${ }^{13}$ Finally, it provides us with new information and new perspectives on Benjamin's business and corroborates evidence from other sources. The open letter to the Convention began with an emotional appeal:

My husband is in irons by virtue of a decree of accusation that is based on denunciations which have not been contradicted. The indictment has not been drawn up; the tribunal that will judge him has not been determined, \& yet no one is communicating with him. He is in solitary confinement, \& remains charged with the execution of numerous deal[s]; obliged to follow a multitude of operations of which he alone is the soul, he is unable to give any orders or to undertake any correspondence. More than two hundred subaltern agents remain under his orders, \& he cannot supervise them.

Continuing in a patriotic tone, Madame Benjamin wrote, "He has provided immense provisions to the nation," but this meant that "the republic" had "a large responsibility" toward him. More than 500,000 livres worth of provisions had already been delivered to Briançon, but the Convention had cancelled these agreements, meaning that Benjamin

\footnotetext{
${ }^{13}$ Sarah Maza, Private Lives and Public Affairs: The Causes Célèbres of Prerevolutionary France (Berkeley: University of California Press, 1993).
} 
was not receiving payments. Meanwhile, every day "additional merchandise arrives from all over, which he had to provide in advance, not being able to predict that his contracts would be nullified.” Moreover, Benjamin had made agreements with subcontractors who were now demanding to be paid. "All our fortune,” the petitioner continued, "\& much more, is therefore visibly absorbed by these vast enterprises." She depicted a "frightful chaos” in which “numerous creditors are still fighting over the remains” of Benjamin’s enterprise while her husband "trembles in a narrow prison."

Alluding to the effects of anti-Jewish sentiment, Madame Benjamin wrote, “I know that terrible prejudices still rise up against us, that a baneful suspicion calls into disfavor all the business ventures of my husband.” She nonetheless expressed confidence that "the convention is too just to allow itself to be carried away by appearances that are often deceptive." It would "not permit us to be ruined, if our ruin must be the consequence of a precipitous judgment rather than of real crimes on our part.” The petitioner was asking for two things: first, for a speedy trial in order for Jacob to prove his innocence and then return to his business; and second, for a reinstatement of the “contracts of Briançon” that had been nullified on November 8.

To prove that Jacob had a record of supplying quality products, his wife gave an account of deals he had made with the government prior to the Briançon agreement. As early as March, 1792, when war was on the horizon but had not been declared, he had “contracted with the minister of war for various supplies of socks \& shoes for Metz \& Strasbourg, the shoes at $5 \operatorname{liv[res]~} 8$ s[ous] per pair, payable in assignats.” In May the government again bought socks and shoes from Benjamin, in addition to "twenty-five thousand shirts at 6 liv[res] each, [payable] in assignats.” No one had complained about 
"the clauses in these initial contracts," which were not under investigation by the Convention, "nor about the exactitude \& the loyalty of the deliveries that followed." "[I]nfinite precautions" had been taken "to assure the quality of this merchandise." Indeed, her husband bought "one hundred ten thousand pairs of shoes" for resale to the army but only accepted them after careful inspection by experts he had hired to assure their quality. Interestingly, Madame Benjamin asserted that "the majority" of the shoes had been "made in a workshop that he established in his house." Outside his house, many in the Marais neighborhood in Paris were involved with "the production of some of the shirts.”

Madame Benjamin was aware of the Convention's complaints about the price Benjamin charged for his meat. She responded by describing his contract with War Minister Servan on June 11, 1792. Benjamin and Servan had agreed to a price of 10 sous, six deniers per pound, but when he travelled to Lyon to begin his deliveries, "he found the troops billeted over the space of one hundred twenty leagues; rather than being united in an army corp, as the agreement had stipulated.” Transportation costs threatened to be ruinous. When Benjamin informed the Minister of War of this hardship, Servan persuaded him "to supply provisionally." Madame Benjamin painted the picture of a supremely patriotic husband:

Benjamin did not refuse anything, \& despite the difficulty of spreading his supplies here \& there, from Lyon to Antibes, \& even as far as Perpignan, he did not think it right to calculate the losses that he was going to suffer.

But the deputies did not have to take Madame Benjamin at her word:

To say how my husband acquitted himself of this burdensome service is to repeat what the entire army of the south has so energetically attested in a declaration that is assuredly not suspect. 
Indeed, Benjamin had received "great praise” from the soldiers at Chambéry, and his wife predicted that they would continue to support "a servant of the patrie who is crushed by misfortune.”

As to the provisioning of "the fortress of Briançon" and that of "Embrun \& of Mont-Dauphin, which are still further away,” Benjamin was offered this commission precisely because he had done such a good job of supplying meat to the Army of the South. But if it had been difficult to provision a dispersed army, supplying Briançon and its neighboring forts was even more burdensome and risky. Madame Benjamin explained that Briançon was "built on the summit of a very high mountain” and that transportation costs were correspondingly high, particularly during the winter when muleteers had to navigate narrow, snow-covered paths.

Madame Benjamin quoted Jean-Pierre Lacombe-Saint-Michel, a deputy who had been tasked with observing the operations of the Army of the South and who had approved of the contract for provisioning Briançon:

Montesquiou sent us the contract with Jacob Benjamin to furnish the army with all the goods that it need[ed]. The battalions were arriving in abundance; that part of the republic was threatened: the need was pressing, the safety of the patrie was at stake. We did not hesitate to give our authorization. ${ }^{14}$

The rush to supply Briançon only added to the cost.

Meanwhile, the contract did not protect Benjamin against losses or damage to his merchandise. The petitioner cited the risk of bandits attacking the caravans or storage facilities. She also pointed to “epizootic diseases, principally among sheep assembled in great quantities," and the "terrible ravages they almost always cause.” Benjamin had to

${ }^{14}$ Cf. Archives parlementaires, vol. 53, 310. 
charge higher prices than usual "to indemnify himself against all these losses.” The author noted that in "all contracts that are aleatory or mixed with risks" the "laws authorize [the price] to exceed the intrinsic value of the thing in question." She pointed to "maritime contracts” in which "the price of risks is computed," and asked, "[H]as one ever made a crime of day laborers who raise the price of freight transportation above all in time of war, of insurers who raise insurance premiums?” Nor were the risks to Benjamin’s merchandise hypothetical. At the time Benjamin agreed to supply Briançon, "in the first days of September, part of the territory of the Republic was invaded by a powerful army.” Proof of the enormity of the risk Benjamin undertook was that "no supplier entered into competition” for the contract. Nor did he need the money. He had "great means, an acquired fortune, rather extensive credit," but "he did not hesitate to expose it all to political uncertainty.”

Madame Benjamin went on to defend the prices her husband charged for specific articles. For example, she justified the sale of salt beef at 27 sous per pound by noting that "[e]veryone knows that before salting meat it is necessary to remove the large bones: the operation of salting requires infinite care.” As to the salt pork that sold for 34 sous per livre, this was because it needed to be delivered in September, whereas "pigs are only slaughtered two months later" and "purchases made before the time of abundance were necessarily more expensive.” 15

Whether Madame Benjamin’s pamphlet had any impact on public opinion is impossible to know, but for the purposes of this essay its value lies in its detailed description of the risks with which Jacob Benjamin’s business was fraught.

${ }^{15}$ La femme de Jacob Benjamin a la Convention Nationale ([Paris, 1792]), 1-13, 22. 


\section{Benjamin in Lyon}

Benjamin arrived in Lyon on December 19 and was imprisoned in the Maison de Justice while awaiting his trial at the Criminal Tribunal of the Rhône-et-Loire Department. On Christmas Day the Convention completed its indictment, which accused Benjamin of selling meat in one contract for up to three times the price he charged in a previous agreement. ${ }^{16}$ Moreover, the indictment charged him with:

$[\mathrm{H}]$ aving concluded with Commissioner Vincent agreements that were fraudulent and prejudicial to the interests of the Republic; having delivered shoes and shirts of the worst quality and having in this way stolen the funds of the Republic and compromised the external security of the State. ${ }^{17}$

These were serious charges, almost as serious as treason, and in time of war might have carried a death sentence.

On January 7, 1793 Benjamin was questioned by Jean-Bernard-François Cozon, president of the Criminal Tribunal, and in the presence of Broches, the public prosecutor. ${ }^{18}$ The transcript of this interrogation is remarkable, both for the amount of detail it provides regarding Benjamin’s enterprise and as a testimony to Cozon’s willingness to listen to the defendant's lengthy explanations of his business practices.

\footnotetext{
16 The indictment notes that according to an earlier agreement with the Minister of War, Benjamin was "obligated to furnish meat to 25[,000] or 30,000 men who were going to compose the Army of the South." Archives Parlementaires, vol. 55, 425.

${ }^{17}$ Archives parlementaires, vol. 55, 425.

18 "'L'an deux de la République et le sept Janvier mil sept cent quatre vingt treize, nous Jean Bernard François Cozon président du tribunal criminel du département du Rone [sic] \& Loire d'après l'envoy fait par le ministre de la justice de l'acte d'accusation porté par la Convention N[ationa]lle contre Jacob Benjamin et Vincent Comm[issai]re ordonnateur avons fait amener en l'auditoire du palais de justice le prévenu cy après nommé et l'avons interrogé en présence de l'accusateur public sur les faits énoncés audit acte d'accusation, et sur les preuves qu'il peut judiquer pour la justification ainsy qu'il suit,” 39 L 21.
} 
When asked about his contract for the provisioning of Briançon, Benjamin noted that it was "under the authority of General Montesquiou” and with the approval of the three deputies from the Legislative Assembly (the precursor to the Convention) whose job it was to supervise the Army of the South. ${ }^{19}$ He confirmed that Commissioner Vincent had succeeded in negotiating a reduction in the price of mutton from 27 to 23 sous per pound. When Cozon asked about any previous deals Benjamin had made with War Minister Servant, Benjamin discussed the contract from June 11 "for the supply of meat to the entire Army of the South.” According to this agreement he was to:

[D]eliver the meat at the price of 10 sous 3 deniers per pound if the head and the pluck [fraissure] were weighed with the meat, and at the price of 10 sous 10 deniers if the head and the pluck remained in my possession, and finally [at the price] of 10 sous 9 deniers if the heads and pluck were given for free to the soldiers. ${ }^{20}$

Cozon asked Benjamin what accounted for "this enormous difference between the prices fixed by the deal of June 11 and those of the deal of September 3” for the supply of Briançon. He then listened patiently to an extended explanation. Benjamin explained that fresh meat (the object of the contract of June 11) was always cheaper than salted meat, since the former transported itself whereas the latter required the expensive mediation of carters. Moreover, fresh meat "preserves practically all of its weight," whereas salted meat "loses one third [of its weight] through drying, not to mention the large bones that must be removed, and which are a pure loss to the supplier.” Benjamin

\footnotetext{
${ }^{19}$ The deputies in question were Jean-Pierre Lacombe-Saint-Michel, Thomas-Augustin de Gasparin and Jean Pascal Rouyer. Under pressure in the Convention for having approved the unpopular contracts, these deputies denied having agreed on any price and shifted the responsibility to General Montesquiou, who was already the object of severe criticism for an unpopular peace treaty he had concluded with the Republic of Geneva. For the legislative debate on this topic see Archives parlementaires, vol. 53, 310-1.

${ }^{20}$ The pluck consisted of the heart, liver, lungs and other edible soft contents of the animal's body cavities. The difference between the price of 10 sous, 3 deniers if the pluck and head were included but not given to the soldiers and the price of 10 sous, 9 deniers if these parts were given to the soldiers constituted a heavy subsidy by Benjamin of any such gift. It may have contributed to his popularity with the soldiers.
} 
added that for the deal with Servan he received all of his payments in specie, whereas in the contract with Vincent half of his payment was in assignats that lost their value quickly due to inflation. Finally, in the deal of June 11 Benjamin had been indemnified for livestock that died of epidemic disease or was seized "by superior force," whereas the September deal lacked any such guarantee.

Cozon seemed satisfied with this explanation and did not pursue the issue. When Benjamin recalled the contract for 500 horses, Cozon did not ask about the price, which he must have believed to be reasonable. He did ask Benjamin to explain the accusation that he had sold cloth to the army on the basis of length but without stipulating the width. Benjamin replied:

The width of the cloth is not determined in this deal, but it is in a previous contract presented by another supplier, ${ }^{21}$ accepted by the commissioners of the Legislative Assembly, and I took it upon myself in the margin of this contract to take the width determined in [the previous] contract as the rule for my supply, and to give as a result cloth of the width of one ell and more.

Proof of this was in "the reception reports" written by the army official responsible for accepting supplies. When asked whether he had supplied any shirts to the army, he noted that his "agent” Cerf Dessau had done so and that he (Benjamin) "stood surety” for him. As to the supply of shoes, Benjamin replied, "I never made any deals for the supply of shoes in Lyon. I undertook an engagement in the deal relating to the provisioning of Briançon to supply stockings and shoes at a price of thirteen livres per pair of stockings and shoes together, to be delivered to Briançon," though that deal was "no longer in effect” due to nullification by the Convention. Cozon then asked, “Are you aware that your deals of last September 3 and 23 have been annulled as fraudulent by decree of the

\footnotetext{
21 This supplier was probably Cerf Dessau, who will be discussed later in this essay.
} 
National Convention?” Benjamin did not simply answer this question but defended himself, and Cozon did not interrupt him:

Yes, I am aware from the public papers and because this fact is stated in the indictment but the decree pronouncing this annulment was never shown to me. I submit moreover that these two deals are not at all fraudulent, nor are they detrimental to the interests of the Republic. They are not fraudulent, because I did not employ any fraud in having them accepted, as the commissioners of the Legislative Assembly were empowered, as was the General [Montesquiou], not to agree to my contracts. They are not detrimental to the interests of the Republic, because the Republic could not hope to find suppliers who at this time could supply for a lower price at their peril and risk and without guarantee.

When Cozon was finished with his interrogation, he informed Benjamin of his right to choose "two friends or counsels" to represent him. Benjamin chose a lawyer named Bret. The following day, January 8, Benjamin submitted a petition to the "the citizen judges of the criminal tribunal." It was written in the third person, but this was conventional for legal petitions and does not mean that he did not write it himself, though his lawyer Bret may have authored it in part or in full. In any event, Benjamin himself signed it and there is no signature from Bret. While the petition only asks for Benjamin’s case to be heard at the next court session, it also reveals a defense strategy that combines appeals to existing statutes, humanitarian principles and patriotism.

The petition began by narrating Benjamin’s predicament. On November 20, 1792 "the National Convention decreed that there was cause for an accusation against the petitioner," but “[a] few days prior, called to the bar of the assembly, having gone there, [been] interrogated, [and] sent to the joint committee, the petitioner manifested his innocence and obtained the liberty of his person.” But the "decree of accusation” issued on November 20 “reattached his chains" and Benjamin "accepted them” since this was 
"the will of the representatives of his compatriots." The petition gave the impression that Benjamin had a choice in the matter, asserting, “Jacob Benjamin only burdened himself with these chains in order to obey the law." Yet "if that law was capable of being invoked against him, he had the right to invoke it in turn.”

Accordingly, the petition invoked article 19, title 6 of the penal code, which "prescribes that the public prosecutor immediately after the interrogation shall be required to make haste such that the accused may be judged at the first jury assembly that follows.” (Underlining in the original.) That would have been on December 15, but by that date "no tribunal was yet indicated ... and therefore the petitioner's detention was perpetuated beyond the prescribed term.” Benjamin was "the victim of arbitrary treatment.” The next scheduled session of the criminal tribunal was scheduled for January 15, and this "irrevocably became the jury that must pronounce the fate of the petitioner.” Benjamin was eager to have his day in court:

Far from asking for a dismissal, the petitioner saw with satisfaction the instant of his judgment approaching; his family, his business partners, three hundred agents whom he has to supervise from the depths of his prison, he dares and can say it, the entire army to which he has supplied the subsistence, all are waiting and counting on this moment, their hope must not be deceived, that hope is founded on the law.

Thus, the nation itself and the principles that justified its existence depended on a speedy trial—and implicitly, Benjamin’s acquittal.

The petition acknowledged that the public prosecutor had "the right to ask for a prorogation,” but if he did so he "would have to expose the motives behind his request." But "what would be these motives? Is there one that in the scales of justice could for a moment serve as a counterweight to what reason, humanity, truth demand?” On the 
contrary, “The prorogation that the public prosecutor would request would be on his part a formal admission of the frivolity of the accusation, which he is incapable of defending." To the possible objection that more documentary evidence against Benjamin was forthcoming, the petitioner remarked that "to ask for a delay on the basis of this hope would be on the part of the public prosecutor to censure the accusation itself and to say that it was at least inconsiderate.” Benjamin (or Bret) appealed again to patriotism and the rule of law: "since the petitioner has been consigned to your authority, an entire army beseeches his presence, three hundred agents his supervision and he who is in irons the execution of the laws." He therefore "request[ed] ... that it please you, Citizens, to ordain that the petitioner will appear before the jury of judgment convoked for the $15^{\text {th }}$ of the current month.”22

Vincent, who had been imprisoned for as long as Benjamin, was also eager to have his day in court, and he also petitioned to have his case judged on January 15 . The public prosecutor, however, asked for a prorogation to the next scheduled session of the criminal court in February. As Benjamin’s petition had anticipated, he cited delays in obtaining the necessary documentation. ${ }^{23}$

\section{Business Records Seized from Benjamin's House}

Meanwhile the joint committee established to investigate irregularities in army provisioning sought to build a case against Benjamin and Vincent. It had Benjamin’s house in Paris raided and sent his business records to the Minister of Justice, who in turn

\footnotetext{
${ }^{22}$ Petition from Jacob Benjamin to the judges of the Criminal Tribunal of the Rhône-et-Loire Department, January 8, 1793, 39 L 21.

${ }^{23}$ Petition from Jacques Vincent to the judges of the Criminal Tribunal of the Rhône-et-Loire Department, January 8, 1793, 39 L 21; and Petition from Broches to the judges of the Criminal Tribunal of the Rhôneet-Loire Department, January 8, 1793, 39 L 21.
} 
sent many of them to Broches in Lyon, asking him to have the case tried "at this month's session." 24 Broches then reversed his request of January 8 and asked Cozon to schedule the trial for January 22. ${ }^{25}$ The documents, now in box $39 \mathrm{~L} 21$ at the Archives départementales du Rhône, reveal still more about the extent and nature of Benjamin’s business. Particularly interesting, in this regard, are copies of contracts that Benjamin signed with representatives of France's armed forces. Some of these deals-for the supply of cavalry horses and the provisioning of Briançon, for example-are already known from the Convention's discussion of them. But other contracts provide new information.

Specifically, the June 11 deal between Benjamin and War Minister Servan for the supply of meat is among the documents. This deal was already publically known thanks to Benjamin’s statements before the National Convention and his wife's published plea on his behalf. Benjamin had also mentioned it to Musset during his interrogation in Paris, and again to Cozon while under questioning in Lyon. But the contract itself, a 21article document, reveals more than the agreed upon price of the meat. Article one indicates that Benjamin was required to provide meat for the soldiers in the Army of the South wherever they were "assembled in an army, whether in France or in foreign countries." Article two shows that Benjamin was obligated to provide one half pound of meat every day for every soldier in the Army of the South from July 1 to December 31, 1792. In other words, it literally charged Benjamin with feeding an army. The contract estimated that there were between 28,000 and 30,000 soldiers in that army. One quarter of the cattle were to be oxen (boeufs) and one quarter cows “of high quality,” the oxen

\footnotetext{
${ }^{24}$ Dominique-Joseph Garat, Minister of Justice, to Broches, public prosecutor, January 12, 1793, 39 L 21.

${ }^{25}$ Broches, public prosecutor, to Jean-Bernard-François Cozon, presiding judge of the Criminal Tribunal of the Rhône-et-Loire Department, January 18, 1793, 39 L 21.
} 
weighing at least 500 pounds a head (and the weight of the cows undetermined).

According to article three the hides, tallow and offal were to remain in Benjamin's possession. (Benjamin also sold candles, perhaps using some of these by-products of slaughtered animals, and his business partner Cerf Dessau sold leather goods to the army. ${ }^{26}$ ) Article four required Benjamin to pay any duties on cattle that were brought into France from abroad, indicating an international dimension to the business. Article five provided Benjamin with guards "for the security of the livestock," corroborating his and his wife's claims about the risks to the supply, and an area for the butchering of the animals and the distribution of the meat. Article seven reveals that Benjamin sent his own apprentice butchers and other "employees" to the camps, but that they were to be lodged there or nearby at no cost. Article eight confirms Benjamin's claim to Cozon that there were three rates for the meat depending on its quality and whether the "pluck" was to be given as a gift to the soldiers. The contract also supports Benjamin's contention that the price of meat was lower in the agreement with Servan in part because the state indemnified Benjamin for possible losses. Article eleven required the government to pay Benjamin 290 livres for each ox and 175 livres for each cow that was seized "by major force” or died from “epidemic disease," again revealing the risky nature of his enterprise. $^{27}$

\footnotetext{
${ }^{26}$ The contract to provision Briançon included tallow candles (chandelles). "Approvisionnement des places de Briançon \&c.,” September 3, 1792, 39 L 21. For Dessau's contract with the army, to which Benjamin stood surety, see "Conditions aux quelles le sieur Cerf Dessaut [sic] s'oblige à fournir vingt mille chemises, dix mille chapeaux, dix mill[e] gibernes et avec leurs bandrieres, trois mille bandrieres de sabres, et dix milles paires de guêtres pour le service de l'armée du Midy,” September 6, 1792, 39 L 21.

27 "Conditions sous les quelles Jacob Benjamin demeurant à Paris rue Ste Avoye s'oblige comme pour les progrès deniers et affaires de l'État envers M Joseph Servan ministre et secrétaire d'état ayant le département de la guerre de fournir la viande aux troupes de la nation françoise qui pourroient être rassemblées soit sur les frontières soit en pays étranger soit enfin dans les places et ce jusqu'au $1^{\mathrm{er}}$ janvier 1793,” 39 L 21.
} 
How much would Benjamin have been earned on the basis of this contract? At the upper end, if the army bought only the highest quality meat at 10 livres 10 deniers per pound for 30,000 soldiers, it would have been obligated to pay him 1,494,540 livres. At the lower end, if the army had only purchased the lower-quality meat at 10 livres per pound for 28,000 soldiers, it would have paid Benjamin 1,288,000 livres. ${ }^{28}$ Benjamin received 300,000 livres in advance. ${ }^{29}$

Other contracts shed light on Benjamin’s clothing and cloth supply business. On August 5, 1792 Benjamin agreed to sell the Army of the South 25,000 shirts at seven livres, five sous a piece. That deal was worth 206,250 livres. ${ }^{30}$ Even larger deals were for the supply of cloth out of which uniforms would be made. In one agreement dated August 25, 1792 Benjamin sold 30,000 ells of cloth. In return he received over 600,000 livres (627,500 livres). ${ }^{31}$ Just two weeks later he signed an agreement to sell 32,000 ells of cloth for 708,000 livres. ${ }^{32}$ Benjamin also sold the army tents. Vincent had mentioned the sale of tents in his testimony to the Convention, but the contract itself reveals more about the sale. It shows that Benjamin sold a thousand tents for 224,000 livres. ${ }^{33}$

\footnotetext{
${ }^{28}$ Benjamin recalled in his testimony to Cozon that the meat weighed without the pluck was 10 sous, 3 deniers per pound, whereas the contract reveals that he had actually sold it for less: 10 sous per pound.

29 “Conditions sous les quelles Jacob Benjamin demeurant à Paris rue Ste Avoye s'oblige comme pour les progrès deniers et affaires de l'État envers $M$ Joseph Servan ministre et secrétaire d'état ayant le département de la guerre de fournir la viande aux troupes de la nation françoise qui pourroient être rassemblées soit sur les frontières soit en pays étranger soit enfin dans les places et ce jusqu'au $1^{\mathrm{er}}$ janvier 1793,” 39 L 21.

30 “Armée du Midy. 5. Août 1782. Soumission.” Archives départementales du Rhône, 39 L 21. Unless otherwise indicated, all further information in this paper comes from carton $39 \mathrm{~L} 21$.

${ }^{31}$ An ell is a foot and a half. Therefore, 30,000 ells are 45,000 feet. The width of the cloth varied, but it was always at least one ell, thus in this deal Benjamin sold at least 67,500 square feet of cloth. "Armée du midi. Habillem[en]ts. 25 Août 1792. Soumission,” 39 L 21.

32 "Conditions aux quelles le sieur Jacob Benjamin s'oblige à fournir trente deux mille aulnes de drap, pour l'habillement de ce bataillon de Volontaire et Nationaux," September 10, 1792, 39 L 21.

${ }^{33}$ These were large tents. The smallest were 144 square feet, or twelve by twelve feet. (There were 400 of these.) In addition, 600 tents were 216 square feet each. Finally there were 200 officers' tents. The contract does not say how large these were, though they were almost three times as expensive as the small tents. "Soumission," September 15, 1792, 39 L 21.
} 
In all, the contracts in the court dossier show deals worth at least 3.9 million

livres. (See Table 1.) Of course, we cannot know what Benjamin’s profit margins were, but even if they were as low as 10 percent, Benjamin would have earned at least 390,000 livres in less than three and a half months. This alone would have made Benjamin one of the highest-earning people in France. By comparison, a rich landowning aristocrat with an annual income of 100,000 livres would have seemed quite modest, and in any event by the end of the summer of 1792 most of that class had already emigrated. ${ }^{34}$ Moreover, the contracts in the court file are only those relating to the supply of the Army of the South.

We know from Musset's interrogation of Benjamin in Paris that he also conducted business with the Army of the Rhine and the Army of the Center. If contracts with these other armies were of comparable value — and only a thorough search of War Ministry archives will establish whether this was the case —-then Benjamin would have had done roughly 12 million livres worth of business with the state in $1792 .{ }^{35}$

Table 1.

\begin{tabular}{|l|l|l|}
\hline Contract & Date (1792) & Value (in livres) \\
\hline $\begin{array}{l}\text { Meat supply for the } \\
\text { entire Army of the } \\
\text { South }\end{array}$ & June 11 & $\begin{array}{l}1,288,000 \text { to } \\
1,494,540\end{array}$ \\
\hline 25,000 shirts & August 5 & 206,250 \\
\hline 30,000 ells of cloth & August 25 & 627,500 \\
\hline $\begin{array}{l}\text { Provisioning of } \\
\text { Briançon }\end{array}$ & September 3 & At least $500,000^{36}$ \\
\hline
\end{tabular}

\footnotetext{
${ }^{34}$ According to Timothy Tackett, the marquis de Lafayette had an income of 108,000 livres in 1778. Only a few aristocrats had higher incomes than that. Becoming a Revolutionary: The Deputies of the French National Assembly and the Emergence of a Revolutionary Culture (1789-1790) (Princeton: Princeton University Press, 1996), 30.

${ }^{35}$ Still more evidence of lucrative contracts with other armies comes from Madame Benjamin's open letter to the Convention in which it is reported that Benjamin sold 100,000 shirts to the military. The August 5 contract with the Army of the South was only for 25,000 shirts, which suggests that the other 75,000 shirts were sold to other armies.

${ }^{36}$ The exact amount cannot be estimated, since the sheep were sold by head and their weight is unknown. Assuming that the average sheep weighed 200 pounds, the contract would have been worth 538,731 livres.
} 


\begin{tabular}{|l|l|l|}
\hline 30,000 ells of cloth & September 10 & 708,000 \\
\hline 1000 tents & September 15 & 224,000 \\
\hline 500 horses & September 23 & 360,000 \\
\hline & & Total (lowest \\
& & estimate) \\
& & $3,913,750$ \\
\hline
\end{tabular}

The papers seized by the Convention also reveal Benjamin’s connections with other Jewish businessmen. Specifically, the name Cerf Dessau (a recognizably Jewish name) appears frequently in the documents. (Benjamin mentioned Dessau while under interrogation by Cozon.) Benjamin stood surety for two contracts worth more than 850,000 livres altogether in which Dessau supplied the army. ${ }^{37}$ Another of Benjamin’s associates, Isaac Hesse, was likely Jewish. He stood surety for the contract (worth 708,000 livres) in which Benjamin agreed to provide cloth for soldiers’ uniforms. ${ }^{38}$ When Benjamin needed someone to co-sign his agreement to sell the army 500 cavalry horses, he chose the Jewish businessman Bernard Alcan. ${ }^{39}$ In his challenging quest to provide daily meat rations for roughly 30,000 men, Benjamin formed a corporation with two other Jewish men: Aaron Schemolle (the "Chemol" mentioned in the interrogation by Musset and Benjamin's neighbor on the rue Capon in Paris) and Jacob Trenelle. ${ }^{40}$ We can only guess at how many of Benjamin’s 300 agents (préposés) were Jewish. Clearly Benjamin could not have done his work without a network of Jewish merchants.

\footnotetext{
${ }^{37}$ Contract between Cerf Dessau and General Montesquiou, August 22, 1792; and "Conditions aux quelles le sieur Cerf Dessaut [sic] s'oblige à fournir vingt mille chemises, dix mille chapeaux, dix mill[e] gibernes et avec leurs bandriers, trois mille bandriers de sabres, et dix milles paires de guêtres pour le service de l’armée du Midy,” September 3, 1792, 39 L 21.

38 "Conditions aux quelles le sieur Jacob Benjamin s'oblige à fournir trente deux mille aulnes de drap, pour l'habillement de ce bataillon de Volontaire et Nationaux," September 10, 1792.

39 “Chevaux. Armée du midi. Soumission,” September 21, 1792, 39 L 21. Cf. Archives Parlementaires, vol. 53, 310.

${ }^{40}$ Act of incorporation “par devant les notaires de Paris,” June 22, 1792, 39 L 21.
} 
In supplying French armies, Jewish entrepreneurs were continuing an Old Regime practice. As early as 1698 an intendant of Metz wrote a memorandum justifying the presence of Jews in part on the basis of their utility in providing cavalry horses and other items to the French army. ${ }^{41}$ Jay Berkovitz has found that the late eighteenth-century records of the beit din of Metz include many cases relating to army provisioning enterprises. $^{42}$ Yet the Revolution appears to have increased the opportunities for Jewish army contractors by eliminating restrictions on Jewish mobility and augmenting the size of the nation's fighting force.

\section{The Trial}

The trial finally took place on January 22, 1793. The Archives départementales du Rhône contain a printed record of the trial (box 39 L 60), though this document is a form describing the procedure of all criminal trials, with sparse handwritten commentary. Unfortunately it does not tell us what the lawyers, defendants or witnesses said. But the form does contain important information. The trial began with Cozon, the president of the tribunal, calling both Benjamin and Vincent to appear before the bench, "free and without irons.” Afterwards the twelve jurors, sitting at the left of the judges, stood up and Cozon administered "the oath prescribed by the Law" to them, to which they all said, “I swear,” before returning to their seats. ${ }^{43}$ “Citizen Reyre,” Vincent’s defense attorney,

\footnotetext{
${ }^{41}$ Roger Clément, La condition des juifs de Metz sous l'ancien régime (Paris, 1903), 38-42.

42 Jay R. Berkovitz, “Acculturation and integration in eighteenth-century Metz,” Jewish History vol. 24, no. 3/4 (2010): 275.

${ }^{43}$ The jurors were: Antoine Guilloud, Jean Brochet, Jean Baptiste Gagueur, François Lespinasse, Antoine Gabriel Buisson, Pierre Bonnefoy, Pierre Gariot, Pierre Montfalcon, Jean Baptiste Barret, George Ramet, Jean Deschenaud and Claude Vial. L'an second de la République, le vingt deux janvier mil sept cent quatre-vingt treize les Juges du tribunal criminel, l'Accusateur public, étant dans l'auditoire du palais de Justice, chacun à leur place [Lyon, 1793], 39 L 60.
} 
and "Citizen Bret," defending Benjamin, then took "the required oath.” Cozon asked each defendant his name, age, profession and place of residence, and the clerk recorded their answers. The clerk then read the indictment.

Handwritten commentary on the printed record indicates that shirts from the military storage facility were "shown to the accused and to the witnesses" who in turn were asked "if they recognize[d] them." Unfortunately, the record is silent on who the witnesses were or what their (or the defendants') responses were. The public prosecutor and the defense attorneys addressed the court, though again we do not know what they said. Finally Cozon "summarized the case" and gave the jury "written questions and all the documents of the case, with the exception of declarations written by the witnesses.” This was presumably standard procedure, since the quotations in the sentence above are from the printed form, not the handwritten commentary. It is unrealistic to think that the jurors could have read the more than two hundred pages of documentation in the file. No doubt they were relying on Cozon’s having "summarized the case” for them.

By being authorized to compose a questionnaire for the jury, Cozon had a high degree of influence. The questions he gave the jury, which are included in box 39 L 60 in manuscript form, suggest that Cozon was sympathetic to Benjamin:

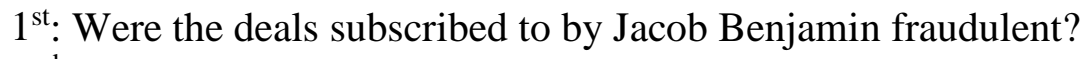

$2^{\text {nd. }}$ Is Jacob Benjamin convicted of fraud for concluding these deals?

$3^{\text {rd. }}$ Did Jacob Benjamin, who is accused of having delivered shirts and shoes of poor quality to the military magazines of Lyon, deliver shoes?

$4^{\text {th}}$ : Did he deliver shirts? 
$5^{\text {th }}$ : Were the shirts that were taken out of said magazines and shown in the audience as exhibits of poor quality?

$6^{\text {th. }}$ : Did these shirts come from deliveries made by Benjamin or by

his agents?

$7^{\text {th }}$ In all of these cases is Jacob Benjamin convicted of the crime

of theft of the Republic's funds, or was he on the basis of his

[illegible] deals subject to a civil action for their execution or annulment? ${ }^{44}$

Then the jurors proceeded to their chamber for deliberation. According to an annotation

on the printed court record, the shirts were brought into the chamber. ${ }^{45}$

The jury voted to acquit both Benjamin and Vincent. With respect to Benjamin,

their declaration affirmed:

"that Jacob Benjamin did not deliver shoes to the military magazines of Lyon, that his agents made deliveries of shirts, that the shirts taken from the magazines and exhibited in the audience are of poor quality, but that it is not certain whether they come from deliveries made by Jacob Benjamin’s agents.

The jurors added "that Jacob Benjamin is not convicted of the crime of theft of the

Republic's funds by reason of his deals and that he was only subject to civil actions

resulting from these deals and their execution.”46

\footnotetext{
${ }^{44}$ The verdict for Vincent also closely followed a questionnaire by Cozon that implicitly raised significant doubts about the prosecution's case. The questionnaire asked whether General Montesquiou and the three deputies supervising the Army of the South (Lacombe-Saint-Michel, Gasparin and Rouyer) had approved of the contracts with Benjamin. (The contracts themselves revealed that these authorities had approved of the deals.) It also asked whether Vincent had signed any certificates accepting the "shirts and shoes of poor quality," an accusation he had vigorously denied. The prosecution had been unable to discover any evidence to the contrary. The jurors therefore concluded that Vincent was "not at all convicted of having favored the theft of the Republic's funds by accepting supplies of shirts and shoes of poor quality, since it is not established that he ever made any reception or acceptance of military effects." "Jacques Vincent. Jacob Benjamin. 22 Janvier 1793,” 39 L 60.

${ }^{45}$ L'an second de la République, le vingt deux janvier..., 39 L 60.

46 “Jacques Vincent. Jacob Benjamin. 22 Janvier 1793,” 39 L 60.
} 


\section{Conclusions}

Jacob Benjamin turned up again in the records of the National Convention, but this time he was not suspected of stealing public funds or endangering the Republic. On the contrary, on September 20,1792, a little less than nine months after he walked out of the Maison de Justice in Lyon a free man, Benjamin was the subject of a letter from the Minister of War, Jean Baptiste Noël Bouchotte, to the Convention, reporting a contribution by the entrepreneur to the continuing war effort. Bouchotte wrote:

Citizen President [of the Convention],

I am forwarding to you a letter from Citizen Jacob

Benjamin by which he announces to me the gift that he made of thirty tents in good condition, with their stakes and cords, and for his brothers in arms of the Section of the Réunion [the militant sans-culotte ward]. I ask you, Citizen President, to please pass it on to the National Convention.

\section{J. Bouchotte}

The letter from Benjamin, written on September 18, read as follows:

Citizen Minister,

The duty of every good citizen is to contribute to the public good, and even to make sacrifices, without looking at his means and his abilities. I have the honor of sending you, citizen minister, for my brothers in arms of the Section of the Réunion who are ready to leave for the frontiers, thirty tents in good condition with their stakes and cords, etc.

I desire that my brothers in arms return soon victorious to their homes after having defeated our enemies.

I am very perfectly, Citizen Minister, your entirely devotedcitizen.

Jacob Benjamin 
This contribution was given "honorable mention” by the Convention and reported in its official bulletin. ${ }^{47}$ It was a significant contribution. According to the contract for tents that Benjamin had signed with Vincent on September 15, 1792, the price of tents ranged from 136 to 410 livres, depending on their size. Even if the tents in the subsequent patriotic gift had been the smallest size, thirty of them would have been worth 4080 livres, more than half the average annual income of a deputy. ${ }^{48}$ But this was not the last of Benjamin’s contributions. On 7 Frimaire Year II (November 27, 1793) Benjamin announced to the sans-culottes of the Réunion section that he was making a gift of 50 tents for the war effort. He also gave coal, wood and wine to the poor-relief fund. The section acknowledged his generosity with a "civic mention."49

I do not know what happened to Jacob Benjamin after November 1793. He is not listed in the F7 series of dossiers on Terror victims at the Archives Nationales in Paris, so he appears to have survived the Terror. ${ }^{50}$ In any event, it is hard to imagine him having been executed without any mention in the Archives Parlementaires or the press. So his is a story with a happy ending, at least as far as I can determine. But what does it mean, and why has it been forgotten?

Let me begin with the second question first. For the French historiography the answer lies perhaps in the density of dramatic events during the fall of 1792 and the winter of 1793. Benjamin's deals with the Army of the South coincided with the fall of the monarchy, the invasion of France by foreign forces and the September Massacres.

\footnotetext{
${ }^{47}$ Archives Parlementaires, vol. 74, 513-4.

48 Tackett, Becoming a Revolutionary, 40.

${ }^{49}$ I am very grateful to Colin Jones of Queen Mary University, London, for providing me with this information in an email of March 20, 2014. Professor Jones found the relevant documentation in: Minutes of the Réunion section, box F7* 2595, Archives Nationales, Paris.

${ }^{50}$ Again I am grateful to Professor Jones for this information. Email from Colin Jones, March 20, 2014.
} 
The Convention's discussion of these deals took place against the backdrop of a much more contentious debate over the fate of the king. And Benjamin's trial took place the day after the king was executed. Under the circumstances it is unsurprising that his story is absent from almost all accounts of the Revolution. As to the Jewish historiography, the story of Jacob Benjamin does not fit well into widely-accepted understandings of the emancipation, which has often been portrayed as a bargain in which Jews had to give up something (communal autonomy, identity, tradition) in return for the elusive promises of liberty and acceptance. Indeed, my own previous work has been informed by this model. ${ }^{51}$ Yet it is not clear what Benjamin had to give up. He grew up in Paris. He did not belong to a kehilla that was in the process of being disbanded or that was burdened with debts from the Old Regime. He called the sans-culottes of his neighborhood his "brothers in arms," and he cheerfully sold many thousands of pounds of pork with no apparent pangs of conscience. The Revolution made him a citizen and also made him very rich. It is true that he suffered the misfortune of imprisonment, but then he was acquitted and soon in the favor of the highest authorities.

Why does Jacob Benjamin matter? At the most basic level, his significance lies in the crucial but unacknowledged role he played in the survival of the Revolution. He fed and clothed tens of thousands of its soldiers at a time when such logistical support might have made the difference between victory and defeat. ${ }^{52}$ But his story is also significant for what it tells us about Jewish-French relations immediately following

\footnotetext{
${ }^{51}$ Ronald Schechter, Obstinate Hebrews: Representations of Jews in France, 1715-1815 (Berkeley: University of California Press, 2003).

${ }^{52}$ On the importance of the relatively neglected study of logistics in military history see John A. Lynn, "The History of Logistics and Supplying War," in John A. Lynn, ed., Feeding Mars: Logistics in Western Warfare from the Middle Ages to the Present (Boulder, CO: Westview Press, 1993), 9-27. I am grateful to Professor Julia Osman of Mississippi State University for bringing this source to my attention.
} 
emancipation. Specifically, it is worth mentioning that the revolutionary government entrusted the vital task of feeding and clothing its armies to a Jew, and less than a year after the emancipation. Furthermore, even though certain revolutionary leaders accused him of serious crimes, antisemitism appears to have played a very small role in the case. It is true that Cambon introduced the army supplier as "le juif Benjamin," but he was unusual in doing so. Almost every other reference to Benjamin in the Archives Parlementaires, as well as in the court records, identified him as "le citoyen Benjamin," or (in pre-republican records) “le sieur Benjamin,” or simply “Jacob Benjamin.””3 More importantly still, no one in the Convention made the case that Benjamin was unpatriotic because he was Jewish. One can imagine a scenario in which at least one deputy claimed that it had been a mistake to emancipate the Jews, or even that Jews were taking advantage of the generous revolutionary laws to profit at the expense of the brave soldiers who were risking their lives for the principle of equality. After all, little more than a year prior to Benjamin’s appearance at the bar of the Convention deputies had argued about whether Jews were capable of citizenship. Yet no one even hinted at the need to revisit emancipation. Deputy Jean-François Rewbell, who had argued vociferously against Jewish political equality while serving in the Constituent Assembly in 1789 to 1791, was present in the Convention during the discussion of Benjamin. He even spoke on November 20, 1792, following the reading of the letter from Deputies Alquier, Boissy

\footnotetext{
53 In over 200 pages of documentation in box 39 L 21 Benjamin's Jewishness is only mentioned three times. Deputy Musset's interrogation identified the suspect as "Benjamin Jacob [sic] Juif." "Interrogatoire de Jacob Benjamin du 13 9bre l'an 1er [de la République].” A letter from the deputies en mission in Lyon to the Convention's Surveillance Committee, denounced an army official named Vass for having written reception reports for shoddy merchandise, claiming that "it is he who favored the brigandage, in the midst of war, of the Jew Benjamin.” Charles-Jean-Marie Alquier, François Antoine de Boissy d'Anglas and Louis Vitet to the Surveillance Committee, November 21, 1792. Finally, a deposition by two businessmen of Lyon reported that they had visited the army storage facility in Lyon and examined covers of uneven quality from a delivery by "Jacob Benjamin Juif." Deposition of Vincent Perret and Jacques Ordassiere, December 1, 1792.
} 
d'Anglas and Vitet accusing Benjamin of additional depredations. But he said nothing about Benjamin or the Jews in general. Rather he said that the war ministers were ultimately responsible for any peculation in army contracts and that they should be indicted. ${ }^{54}$ Why antisemitism so quickly and dramatically disappeared from political discourse is an interesting question, to which I do not have a ready answer, but for the purposes of my argument it is sufficient to note that antisemitism is almost entirely absent from the relevant political and judicial documentation.

If the twelve jurors in Lyon had been antisemitic, it is unlikely they would have acquitted Benjamin, despite the coaching they appear to have received from Cozon. Furthermore there is clearly no sign of antisemitism in Cozon, who actively resisted the rush on behalf of the Convention to see Benjamin (and Vincent) punished.

To be sure, it is possible that political considerations motivated Cozon and the jury, just as political considerations motivated the deputies who sought to prove that they were good stewards of the nation's resources. In this respect it may be relevant that the trial of Benjamin and Vincent took place on January 22, 1793. On January 21, a much more famous suspect had gone to the guillotine: Louis XVI. Though news of the event may not have reached Lyon yet, the king had already been condemned to death on January 17. Whether and to what extent the execution impacted Cozon or the jury in the case of Benjamin and Vincent are matters of speculation. The execution of the king was unpopular in the provinces, and perhaps the Lyonnais, in particular, were reluctant to give the regicide Convention what it wanted in the case of Benjamin and Vincent. After all, less than six months later Lyon, France’s second city, would be in rebellion against the

\footnotetext{
54 Archives Parlementaires, vol. 53, 492.
} 
Paris-based legislature. During that rebellion the Jacobin activist Joseph Chalier was executed, and the judge who presided over Chalier's trial was none other than JeanBernard-François Cozon. ${ }^{55}$

But the rivalry between Paris and Lyon does not explain Benjamin’s high standing with the War Minister during the Terror or his warm relations with the sansculottes of the Réunion section. Clearly a wide range of revolutionaries believed that Benjamin was good for the Republic. This does not prove that antisemitic opinion was non-existent among republican legislators, officials and activists, but any such opinion failed to resonate or to affect Benjamin’s standing adversely. It is hard not to read the Benjamin Affair in juxtaposition to the Dreyfus Affair a century later. In the Dreyfus Affair, a man who was manifestly innocent was widely seen as guilty simply because he was Jewish. In the Benjamin Affair, a man whose innocence was less obvious (at what point does an army contractor become a war profiteer?) was nevertheless acquitted and even honored as an extraordinary patriot despite being Jewish; in other words, despite belonging to a long-scorned group in French society. Of course, judicially the two cases were very different. Dreyfus was tried by a military court and Benjamin by a civil court. But in terms of public opinion, the Benjamin case had the same potential to provoke accusations of treason as the Dreyfus case, if not more, since France was fighting for its survival in the fall of 1792 but not in the 1890s. Yet there were no street demonstrations against Benjamin or 'the Jews,' and there was no looting of Jewish businesses. Public opinion in 1792 and 1793 was famously susceptible to conspiracy fears, but none of these seem to have prominently featured the Jews, despite

\footnotetext{
${ }^{55}$ J[ean]-B[aptiste] Monfalcon, Histoire de la ville de Lyon (Lyon, 1851), vol. 3, 955-62.
} 
the publicity of the Benjamin case. ${ }^{56}$ Anyone who would cite the Dreyfus Affair as evidence of a supposed propensity to antisemitism among the French must also reckon with the Benjamin Affair.

${ }^{56}$ Peter R. Campbell, Thomas E Kaiser and Marisa Linton, eds., Conspiracy in the French Revolution (Manchester and New York: Manchester University Press, 2007). 